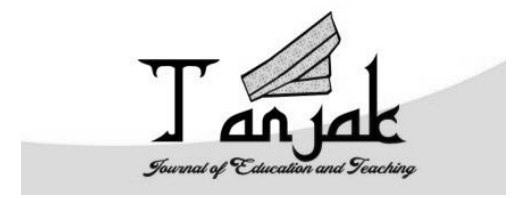 \\ Tanjak: Journal of Education and Teaching \\ ISSN 2716-4098(P)2720-8966 (0) \\ Volume1 Nomor 2, 2020
}

\section{HUBUNGAN KETERAMPILAN MENGAJAR GURU DENGAN MOTIVASI BELAJAR SISWA}

\author{
Mahfuzah Saniah $^{1 *}$, Neli Adriyanti ${ }^{2}$ \\ 1STAIN Sultan Abdurrahman Kepulauan Riau, saniahmahfuzah@gmail.com \\ ${ }^{2}$ Universitas Negeri Padang, neliadriyanti89@gmail.com
}

DOI: https://doi.org/ 10.35961/tanjak.v1i2.153

\begin{abstract}
Abstrak
Masalah dalam penelitian ini adalah masih belum baiknya hasil belajar siswa. Hal ini disebabkan masih rendahnya motivasi belajar siswa. Hal ini terlihat dalam proses belajar hanya beberapa orang siswa saja yang aktif dan tekun mengikuti pelajaran dan banyak siswa yang melakukan aktifitas lain, selanjutnya siswa cendrung mengandalkan tugas dari teman. Tujuan dari penelitian ini adalah untuk mengetahui hubungan antara keterampilan mengajar terhadap motivasi belajar siswa. Penelitian ini adalah penelitian kuantitatif dengan pendekatan ex post facto. Populasi dalam penelitian ini adalah seluruh siswa dan siswi kelas X dan XI Sekolah Menengah Atas Negeri 1 Sungai Pua kabupaten Agam sebanyak 217 orang. Sampel diambil dengan teknik simple random sampling sehingga didapatkan sampel sebanyak 55 orang. Teknik analisis data menggunakan kolerasi product moment. Hasil uji hipotesis dengan menggunakan kolerasi produc moment diperoleh nilai rhiting 0,508 lebih besar dari nilai rtabel 0,266, hal ini berarti terdapat hubungan yang signifikan antara keterampilan mengajar guru dengan motivasi belajar siswa dan berkontribusi sebesar $25,80 \%$.
\end{abstract}

Kata kunci: keterampilan mengajar guru, motivasi belajar siswa

Tanjak: Jounal of Education and Teaching, Vol. 1, No. 2, 2020 


\begin{abstract}
The problem in this research is that student learning outcomes are still not good. This is due to the low student motivation. This can be seen in the learning process, only a few students are active and diligent in attending lessons and many students do other activities, then students tend to rely on assignments from friends. The purpose of this study was to determine the relationship between teaching skills and student motivation. This research is a quantitative study with an ex post facto approach. The population in this study were all students of class X and XI of State Senior High School 1 Sungai Pua, Agam district as many as 217 people. The sample was taken using simple random sampling technique so that a sample of 55 people was obtained. The data analysis technique uses product moment correlation. The results of hypothesis testing using the produc moment correlation obtained rhiting value of 0.508 which is greater than the $r$-table value of 0.266 , this means that there is a significant relationship between teacher teaching skills and student learning motivation and contributes $25.80 \%$.
\end{abstract}

Keywords: teacher teaching skills, student's motivation to study

\title{
Pendahuluan
}

Pendidikan berperan penting dalam mencerdaskan kehidupan bangsa demi peningkatan kualitas sumber daya manusia yang bermutu guna menghasilkan manusia yang berkualitas sesuai dengan fungsi dan tujuan pendidikan Nasional. Proses belajar mengajar merupakan inti dari kegiatan pendidikan di sekolah. Guru merupakan ujung tombak dalam pengembangan sumber daya manusia untuk terus mengikuti berkembangan konsep-konsep baru dalam dunia pendidikan dan pengajaran. Tugas guru dalam proses belajar mengajar meliputi tugas pedagogis dan tugas administrasi.

Untuk melaksanakan tugas keprofesionalan, guru berkewajiban untuk: (a). merencanakan pembelajaran, melaksanakan proses pembelajaran yang bermutu, serta menilai dan mengevaluasi hasil pembelajaran; (b) meningkatkan dan mengembangkan kualifikasi akademik dan kompetensi secara berkelanjutan sejalan dengan perkembangan ilmu pengetahuan, teknologi, dan seni; (c) bertindak objektif dan tidak diskriminatif atas dasar pertimbangan jenis kelamin, agama, suku, ras, dan kondisi fisik tertentu, atau latar belakang keluarga, dan status sosial ekonomi peserta didik dalam pembelajaran; (d) menjunjung tinggi peraturan perundang-undangan, hukum, dan kode etik guru, serta nilai-nilai agama dan etika; dan (e) memelihara dan memupuk persatuan dan kesatuan bangsa, (UU-RI No.14 tahun 2005 pasal 20 tentang Guru dan Dosen).

Dalam merealisasikan serta mewujudkan tugasnya, guru harus mengetahui bagaimana kiat dan strategi dalam mentransfer ilmu dan pengetahuan merupakan hal yang harus dimiliki seorang guru. Untuk mengimplementasikan proses belajar mengajar yang ideal, guru wajib untuk : (1) merencanakan serta menyusun materi pembelajaran, (2) melaksanakan proses pembelajaran, (3) menggunakan metode dalam pembelajaran dengan strategi, cara serta pendekatan yang digunakan dalam pembelajaran, (4) menciptakan situasi dan kondisi yang efektif dalam proses pengajaran, (5) menggunakan media untuk membantu dalam proses pembelajaran, (6) mengevaluasi dan melihat seberapa jauh tingkat efektifitas serta usaha-usaha apa yang dilakukan seorang guru untuk menimbulkan minat serta daya tarik bagi siswa dengan memberikan umpan balik kepada sisiwa, (7) memberikan perbaikan dari hasil proses pembelajaran (remedial), (8) melaksanakan semua proses pembelajaran yang mengacu pada tuntutan kurikulum yang dipakai, (9) memperhatikan kondisi peserta didik.

Dalam proses belajar mengajar terjadi proses interaksi antara guru dan siswa, serta siswa dengan siswa itu sendiri dan hubungan ini berlaku secara timbal balik. Agar proses pembelajaran 
berjalan dengan lancar diperlukan kerjasama oleh semua pihak di atas. Selain itu juga terdapat beberapa faktor yang mempengaruhi keberhasilan siswa dalam belajar antara lain, dapat berasal dari dalam diri siswa maupun dari luar diri siswa itu sendiri (Prayitno, 2007). Faktor dari dalam diri siswa meliputi bakat, minat belajar, motivasi belajar, faktor pematangan dan pertumbuhan lainnya. Sedangkan dari luar diri individu meliputi faktor lingkungan, keluarga, masyarakat, guru atau dosen, alat-alat dan sarana prasarana mengajar lainnya.

Menurut Walker (Dalam Ahmad, 2004) suatu aktivitas belajar sangat lekat dengan motivasi. Perubahan suatu motivasi akan merubah pula wujud, bentuk dan proses belajar. Ada tidaknya motivasi seorang individu untuk belajar sangat berpengaruh dalam proses aktivitas belajar itu sendiri. Motivasi merupakan salah satu faktor yang dapat meningkatkan kualitas pembelajaran, karena siswa akan belajar dengan sungguh-sungguh apabila memiliki motivasi yang tinggi. Dalam menciptakan dan merangsang motivasi yang baik dalam belajar tentu banyak faktor yang mempengaruhinya. Ada beberapa ahli yang mendefenisikan tentang pengertian motivasi. Menurut Dalyono (1997) motivasi adalah sebagai tenaga penggerak atau pendorong untuk melakukan sesuatu pekerjaan guna untuk mencapai tujuan. Elida (1989) mengartikan motivasi merupakan salah satu energi yang menggerak siswa untuk belajar, tetapi juga sebagai salah satu penggerak kreatifitas belajar kepada tujuan belajar. Disisi lain McDonald dan Hamalik (2000) menyatakan bahwa motivasi adalah perubahan energi dalam diri seseorang ditandai dengan munculnya filing dan didahului dengan tanggapan dan tujuan.

Callahan dan Clark dalam Mulyasa (2005) mengemukakan bahwa motivsi adalah tenaga pendorong atau penarik yang menyebebkan adanya tingkah laku kearah suatu tujuan tertentu. Sedangkan prayitno (1999:8) menyatakan bahwa motivasi dalam belajar tidak hanya merupakan suatu energi yang mengerakan siswa untuk belajar tetapi juga sebagai suatu yang mengarahkan aktivitas siswa terhadap tujuan belajarnya. Sementara itu Winkel (1983) bahwa motivasi belajar adalah keseluruhan daya penggerak didalam diri siswa untuk menimbulkan kegiatan belajar dan memberikan arahan pada kegiatan belajar itu. Maka tujuan yang dikehendaki dapat tercapai. Sardiman (2008) mengatakan bahwa motivasi belajar adalah keseluruhan daya pengerak didalam diri siswa yang menimbulkan kegiatan belajar yang menjamin kelangsungan dari kegiatan belajar, dan memberi arah kepada kegiatan belajar sehingga tujuan yang dikehendaki oleh subjek belajar itu dapat tercapai.

Menurut Sadirman (2008:89) motivasi terbagi antar dua bentuk antar lain: (a) Motivasi Intrinsik yaitu motivasi instirinsik adalah motif-motif yang menjadi aktif atau fungsinya tidak perlu dirangsang dari luar karena dalam diri setiap individu sudah ada dorongan untuk mengeluarkan sesuatu. (b) Motivasi Ekstrinsik yaitu motivasi motif-motif yang aktif dan berfungsi karena adanya perangsang dari luar. Motivasi ekstrinsik ini tidak baik tapi dalam proses pembelajaran perlu, sebab kemungkinan besar keadaan siswa tidak dinamis, berubah-ubah dan mungkin komponen lain dalam proses pembelajaran ada yang kurang menarik bagi siswa sehingga diperlukan motivasi eksterinsik. Motivasi memilki fungsi yaitu: (1) Mendorong manusia untuk berbuat, jadi sebagai pengerak atau motor yang melepaskan energi, (2) Menetukan arah perbuatan, sebagai arah tujuan yang dicapai, (3) Menyelesaikan perbuatan, menetukan perbuatan-perbuatan apa yang harus dicapai yang berarti guna mencapai tujuan. (Nasution, 1995).

Secara teori motivasi dipengaruhi oleh banyak faktor diantaranya adalah guru, metode yang dipakai, dari diri siswa tersebut seperti untuk kematangan, keinginan untuk mengembangkan kreativitas, dan dari keluarga siswa. (Dimyanti, D \& Mudjiono, D, 2002). Berdasarkan penjelasan sebelumnya, 
dalam melahirkan motivasi belajar peran guru sangatlah dominan. Guru merupakan model dan motivator terdekat bagi siswa dalam merangsang dan menumbuhkan motivasi yang baik dalam belajar. Oleh sebab itu keterampilan yang mumpuni harus dimiliki oleh setiap guru dalam memotivasi siswa.

Keterampilan merupakan suatu kemampuan di dalam menggunakan akal, fikiran, ide serta kreatifitas dalam mengerjakan, mengubah atau juga membuat sesuatu itu menjadi lebih bermakna sehingga dari hal tersebut menghasilkan sebuah nilai dari hasil pekerjaan tersebut (Wikipedia). Robbins (2000) menyatakan pendapatnya bahwa keterampilan ini dibedakan atas 4 katergori, yakni sebagai berikut. (1) Basic Literacy Skill merupakan suatu keahlian dasar yang dimiliki oleh tiap-tiap orang, misalnya seperti menulis, membaca, mendengarkan, atau juga kemampuan dalam berhitung. (2) Technical Skill merupakan suatu keahlian yang didapat itu dengan melalui pembelajaran didalam bidang teknik, misalnya seperti menggunakan komputer, memperbaiki handphone, serta lain sebagainya. (3) Interpersonal Skill merupakan suatu keahlian tiap-tiap orang dalam melakukan komunikasi antar sesama, contohnya seperti mengemukakan pendapat serta bekerja bersama dalam tim. (4) Problem Solving merupakan suatu keahlian seseorang di dalam memecahkan sebuah masalah dengan menggunakan logikanya.

Mengajar menurut Ali (2008) adalah "upaya dalam memberikan rangsangan (stimulus), bimbingan, dorongan kepada siswa agar terjadi proses belajar mengajar. Mengajar diartikan sebagai suatu usaha menciptakan kondisi atau sistem lingkungan yang mendukung dan memungkinkan berlangsungnya proses belajar mengajar, (Hasibun,1993:). Sejalan dengan Hasibuan, moh. Usman Uzer (2008) mengungkapkan bahwa, pada prinsipnya mengajar adalah membimbing siswa dalam kegiatan belajar atau suatu usaha mengorganisasi lingkungan dalam hubungannya dengan peserta didik dan bahan pengajaran yang menimbulkan proses belajar. Sedangkan menurut Sardiman (2007:48) mendefinisikan "mengajar adalah upaya menciptakan kondisi yang kodusif untuk berlangsungnya kegiatan belajar bagi para siswa".

Selanjutnya Ali (2008) mengartikan "Mengajar adalah segala upaya yang disengaja dalam rangka memberi kemungkinan bagi siswa untuk terjadi proses belajar sesuai dengan tujuan yang dirumuskan". Dari pengertian dan uraian di atas dapat dikatakan bahwa mengajar adalah kegiatan seorang guru pada saat kegiatan belajar mengajar berlangsung, dimana guru sebagai faktor utama dalam mengajar. Keterampilan mengajar merupakan faktor utama bagi setiap guru sebelum berdiri di depan kelas. Dengan penguasaan keterampilan dasar akan memudahkan guru dalam mengelola setiap kegiatan yang akan dilakukan dalam setiap interaksi dalam belajar mengajar.

Keterampilan dasar yang harus dimilki setiap guru tersebut menurut Usman (2008) adalah sebagai berikut: 1). Keterampilan bertanya (Questioning skill), 2). Keterampilan memberikan penguatan (reinforcement skill), 3). Keterampilan melakukan variasi (variation skill), 4). Keterampilan menjelaskan (explaning skill), 5). Keterampilan membuka dan menutup pelajaran (set inducation closure), 6). Ketermpilan membimbing kelompok kecil, 7). Keterampilan mengelola kelas, 8) keterampilan mengajar perseorangan.

Dalam proses belajar mengajar di dalam kelas maupun di lapangan tidak lepas dari ketrampilan mengajar seperti yang dikemukakan di atas. Terlaksananya interaksi belajar mengajar antar guru dengan siswa ditentukan oleh seberapa besar seorang guru menguasai keterampilan mengajar yang dimilki seorang guru serta dilaksanakan dengan baik, maka akan memudahkan guru tersebut mengelola pelajaran itu sendiri sehingga hasil yang diperoleh sesuai dengan apa yang diinginkan. Keterampilan 
mengajar yang dimiliki guru sejarah, seharusnya mampu meningkatkan motivasi siswa terhadap pelajaran sejarah sehingga pembelajaran berjalan dengan baik. Dari hasil observasi dan wawancara dengan siswa yang penulis lakukan mengenai persepsi siswa tentang keterampilan mengajar guru diperoleh gambaran awal yaitu, Interaksi antara guru dan siswa masih kurang seimbang dimana dalam pembelajaran berlangsung guru hanya sibuk menerangkan materi pelajaran sedangkan siswa hanya menerima saja, sehingga suasana pembelajaran menjadi tidak akrab. Begitu juga dalam kegiatan kelompok, setelah guru sejarah memberikan materi yang akan didiskusikan, setelah itu siswa mengerjakan dengan teman sekelompoknya dan guru hanya mengawasi, sehingga dalam penyampaian hasil diskusi tidak sesuai dengan apa yang diharapkan karena diskusi berjalan dengan kaku.

Penelitian ini bertujuan untuk melihat hubungan keterampilan mengajar guru dengan motivasi belajar siswa. Dalam realisasi penelitian ini, penulis mengumpulkan data siswa dan data guru yang bertindak sebagai objek penelitian. Dalam penelitian ini penulis menggunakan APKG (Alat Penilaian Kemampuan Guru) sebagai indikator untuk mengukur keterampilan mengajar guru yang dikeluarkan oleh oleh dinas pendidikan, dan pada APKG ini penulis hanya menggunakan APKG-2 yaitu prosedur dalam pembelajaran, dengan indikator sebagai berikut:

1. Keterampilan mengelola tugas

2. Keterampila menggunakan strategi pembelajaran

3. Keterampilan berkomunikasi dengan siswa

4. Keterampilan mendemonstrasikan khasanah metode mengajar

5. Keterampilan mendemonstrasikan penguasaan mata pelajaran dan relevansi

6. Keterampilan mendorong dan menggalakan keterlibatan siswa dalam proses pembelajaran

7. Keterampilan melaksanakan evaluasi hasil belajar

8. Keterampilan menutup pembelajaran

9. Kesan umum pelaksankan pembelajaran

Berdasarkan indikator keterampilan mengajar guru dalam APKG, yang mana pada indikator ini sejalan dengan pendapat beberapa para ahli diantaranya, Yutmini (1992) mengemukakan, persyaratan kemampuan yang harus dimiliki guru dalam melaksanakan proses belajar mengajar meliputi kemampuan: (1) menggunakan metode belajar, media pelajaran, dan bahan latihan yang sesuai dengan tujuan pelajaran, (2) mendemonstrasikan penguasaan mata pelajaran dan perlengkapan pengajaran, (3) berkomunikasi dengan siswa, (4) mendemonstrasikan berbagai metode mengajar, dan (5) melaksanakan evaluasi proses belajar mengajar.

Menurut teori Behavoristik Thorndike, belajar adalah proses interaksi antara stimulus dan respon. Stimulus adalah sesuatu yang dapat merangsang terjadinya kegiatan belajar, sedangkan respon adalah reaksi atau tanggappan yang dimunculkan peserta didik ketika belajar terhadap stimulus yang diberikan. Menurit Thorndike perubahan tingkah laku akibat dari kegiatan belajar dapat terwujud konkrit yaitu yang dapat diamati, atau tidak dapat diamati (Budiningsi, 2005). Demikian juga dengan motivasi belajar siswa dipengaruhi oleh keterampilan mengajar yang dimiliki oleh seorang guru. Dengan keterampilan mengajar yang dimiliki oleh seorang guru akan menimbulkan suatu tanggapan atau persepsi siswa terhadap keterampilan mengajar guru yang akan meningkatkan motivasi belajar, sehingga siswa tertarik dalam belajar, dan memilki motivasi belajar yang tinggi dalam mengikuti pelajaran.

Berdasarkan uraian teori di atas dapat pahami bahwa dalam kegiatan pembelajaran, persepsi siswa tentang keterampilan mengajar guru yang diterapkan guru dalam mengajar dan menerangkan materi pelajaran itu merupakan stimulus yang diberikan oleh guru yang akan di tarik kesimpulan oleh 
siswa atas yang dilihatnya dari tindakan tersebut yang dilakukan guru dan akhirnya mempengaruhi motivasi siswa dalam proses belajar mengajar.

Secara teori motivasi dipengaruhi oleh banyak faktor diantaranya guru, metode yang dipakai, dan faktor yang berpengaruh dari individu itu sendiri, seperti untuk kematangan, keinginan untuk mengembangkan kreatifitas, mudjiono (2002). Sumbangan dari guru sangat mempengaruhi motivasi belajar siswa, diantaranya adalah keteampilan mengajar yang dimilki oleh guru. Jika seorang guru memiliki keterampilan mengajar yang baik maka siswa akan memiliki persepsi terhadap keterampilan guru baik itu persepsi yang positif maupun negatif, jika siswa memiliki persepsi yang positif dia akan termotivasi untuk belajar, dan jika siswa memiliki persepsi yang negatif hal ini akan cendrung untuk tidak mau belajar atau memiliki motifasi yang rendah. Berdasarkan penjelasan di atas dapat diketahui adanya hubungan yang kuat antara persepsi siswa tentang keterampilan mengajar guru dengan motivasi belajar siswa.

Dengan demikian dapat diasumsikan jika seorang guru memiliki keterampilan mengajar yang baik, akan menimbulkan persepsi siswa terhadap keterampilan mengajar guru baik itu persepsi yang positif maupun negaitif. Siswa memilki persepsi positif akan cendrung memiliki motivasi dan akan mendorong bekerja keras dalam belajar dibandingkan pada seseorang yang memiliki persepsi negatif yang akan cendrung yang tidak bermotivasi dan rasa bosan dalam belajar.

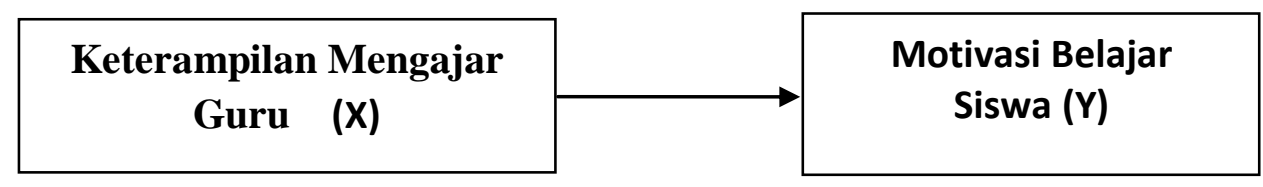

Gambar 1. Hubungan keterampilan mengajar dengan motivasi

\section{Metode Penelitian}

Penelitian ini bersifat ex post facto, karena penelitian ini tidak mencoba memanipulasi fariabel penelitian, peristiwa itu terjadi, yang dilakukan untuk meneliti peristiwa yang telah terjadi yang kemudian merunut ke belakang untuk mengetahui faktor-faktor yang dapat menimbulkan kejadian tersebut (Iskandar 2008). Populasi adalah keseluruhan subjek penelitian (Suharsimi, 2006). Populasi pada penelitian ini adalah siswa kelas X dan XI SMA N 1 Sungai Pua yang terdaftar pada semester Januari - Juni tahun pelajaran 2017-2018 berjumlah 217 orang siswa. Sampel adalah sebagian atau wakil populasi yang akan diteliti. Dinamakan penelitian sampel apabila kita bermaksud mengeneralisasikan hasil penelitian sampel. Maksudnya mengangkat penelitian sebagai suatu yang berlaku bagi populasi (Arikunto, 2007). Teknik pengambilan sampel yang digunakan adalah sampel random sederhana (Simple Random Sampling) karena semua anggota populasi memiliki kesempatan yang sama untuk dijadikan sampel. Untuk menetapkan anggota sampel penelitian berpedoman kepada Arikunto (2006) yang menyatakan bahwa apabila subjektifnya kurang dari 100 orang maka lebih baik diambil semuanya agar penelitian menjadi penelitian populasi, tetapi jika jumlah subjeknya besar maka dapat diambil antara $10-15 \%$ atau $20-25 \%$. 
Table 1. kisi-kisi instrument penelitian

\begin{tabular}{|c|c|c|c|c|}
\hline No & Variabel & Indikator & Nomor item & Jumlah \\
\hline 1 & $\begin{array}{l}\text { Persepsi } \\
\text { siswa } \\
\text { tentang } \\
\text { keterampila } \\
\text { n mengajar } \\
\text { guru }\end{array}$ & 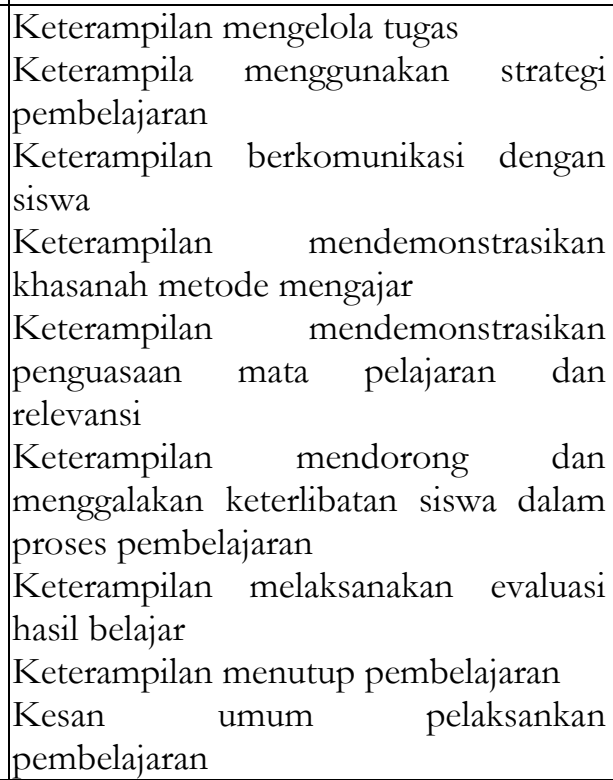 & $\begin{array}{l}1,2,3, \\
4,5,6,7 \\
8,9,10,11 \\
12,13,14, \\
15,16 \\
17,18,19,20 \\
21,22,23 \\
24,25,26 \\
27,28\end{array}$ & $\begin{array}{l}4 \\
3 \\
2 \\
4 \\
3\end{array}$ \\
\hline & & & Jumlah & 28 \\
\hline \multirow[t]{2}{*}{2} & $\begin{array}{l}\text { Motivasi } \\
\text { belajar }\end{array}$ & $\begin{array}{l}\text { Ketekunan dalam belajar } \\
\text { Ulet } \\
\text { Senang dalam belajar } \\
\text { Mandiri dalam mengerjakan tugas } \\
\text { Dapat mempertahankan pendapat } \\
\text { Tidak mudah melepaskan apa yang } \\
\text { diinginkan }\end{array}$ & $\begin{array}{l}1,2,3,4,5,6, \\
8,9,10,11,12 \\
13,14,15 \\
16,17,18,19 \\
20,21,22 \\
23\end{array}$ & $\begin{array}{l}6 \\
6 \\
3 \\
4 \\
3 \\
1\end{array}$ \\
\hline & & & Jumlah & 23 \\
\hline
\end{tabular}

Uji hipotesis menggunakan rumus korelasi product moment (Ari kunto 2007) rumus product moment adalah sebagai berikut:

$\mathrm{rxy}=\frac{\mathrm{n} \sum \mathrm{xy}-\left(\sum \mathrm{x}\right) \mathrm{x}\left(\sum \mathrm{y}\right)}{\sqrt{\left(\mathrm{n}\left(\sum \mathrm{x}^{2}\right)-\left(\sum \mathrm{x}^{2}\right)\left(\mathrm{n} \Sigma \mathrm{y}^{2}\right)-\left(\sum \mathrm{y}^{2}\right)\right)}}$

Korelasi product momen dilambangkan $(\mathrm{r})$ dengan ketentuan nilai $\mathrm{r}$ tidak lebih dari harga $(-1 \leq \mathrm{r} \leq+$ 1) apabila nilai $r=-1$, artinya korelasinya negatif sempurna. $r=0$, artinya tidak ada korelasi dan apabila 
$\mathrm{r}=1$, berarti korelasi sangat kuat. Sedangkan arti harga $\mathrm{r}$ akan dikonsultasikan dengan tabel interprestasi nilai $r$ sebagai berikut:

Table 2. Interprestasi Nilai $\mathrm{r}$

\begin{tabular}{|l|l|}
\hline Interval Koefisien & Tingkat Hubungan \\
\hline $0,800-1,000$ & Tinggi \\
$0,600-0,800$ & cukup \\
$0,400-0,600$ & Agak Rendah \\
$0,200-0,400$ & Sangat rendah \\
$0,000-0,200$ & Tak berkorelsi \\
\hline
\end{tabular}

Sumber Suharsimi Arikunto (2002:245)

\section{Hasil dan Pembahasan}

Berdasarkan penelitian diperoleh data mengenai keterampilan mengajar guru dan motivasi belajar siswa siswa SMA N 1 Sungai Pua melalui penyebaran angket kepada siswa kelas X sebanyak 34 orang, kelas XI sebanyak 21 orang. Angket penelitian dari 55 orang siswa SMA N I Sungai Pua yang dianalisis, terdapat butir pernyataan sebanyak 49 dengan alternatif jawaban Selalu (SL), Sering (SR), Kadang-kadang (KD , Tidak Pernah (TP). Rentang skala 1-4, terdiri dari 9 indikator pada keterampilan mengajar guru dan variabel motivasi belajar siswa.

Berdasarkan angket penelitian hubungan antara persepsi siswa tentang keterampilan mengajar guru dengan motivasi belajar siswa dilakukan pengolahan data dengan menggunakan statistik pada variabel penelitian tersebut. Dari data penelitian diperoleh nilai rata-rata (mean), median, modus, standar deviasi dan varians persepsi siswa rerhadap keterampilan mengajar guru dan motivasi belajar siswa sebagaimana terlihat dari tabel di bawah ini.

Tabel 3. Deskripsi Data Penelitian Persepsi Siswa Tentang Keterampilan Mengajar Guru

\begin{tabular}{|c|c|c|c|}
\hline & & Keterampilan Mengajar Guru & $\begin{array}{l}\text { Motivasi } \quad \text { Belajar } \\
\text { Siswa }\end{array}$ \\
\hline $\mathrm{N}$ & Valid & 55 & 55 \\
\hline & Missing & 0 & 0 \\
\hline Mean & & 85,4000 & 58,6727 \\
\hline Median & & 85,0000 & 58,0000 \\
\hline Mode & & 80,00 & 51,00 \\
\hline Std. Deviation & & 7,29688 & 9,88837 \\
\hline Variance & & 53,244 & 97,780 \\
\hline
\end{tabular}




\begin{tabular}{|l|l|l|}
\hline Range & 32,00 & 40,00 \\
\hline Minimum & 67,00 & 40,00 \\
\hline Maximum & 99,00 & 80,00 \\
\hline Sum & 4697,00 & 3227,00 \\
\hline
\end{tabular}

\section{Motivasi Belajar Siswa}

Data variabel motivasi belajar siswa SMA 1 Sungai Pua didapat dari penyebaran angket pada 55 orang responden. Skor motivasi belajar siswa diperoleh menyevbar skor terendah 40, skor tertinggi 80, skor total sebesar 10961, mean $=58,6727$, median $=58,0000$, modus $=51,00$, dan Standar deviasi 9,88837. Dari perhitungan dasar persepsi motivasi siswa diketahui bahwa skor jawaban menyebar dari skor terendah 40 dan yang tertinggi adalah 80 , sehingga rentang nilai yang tersebar pada sampel adalah 80 $40=40$.

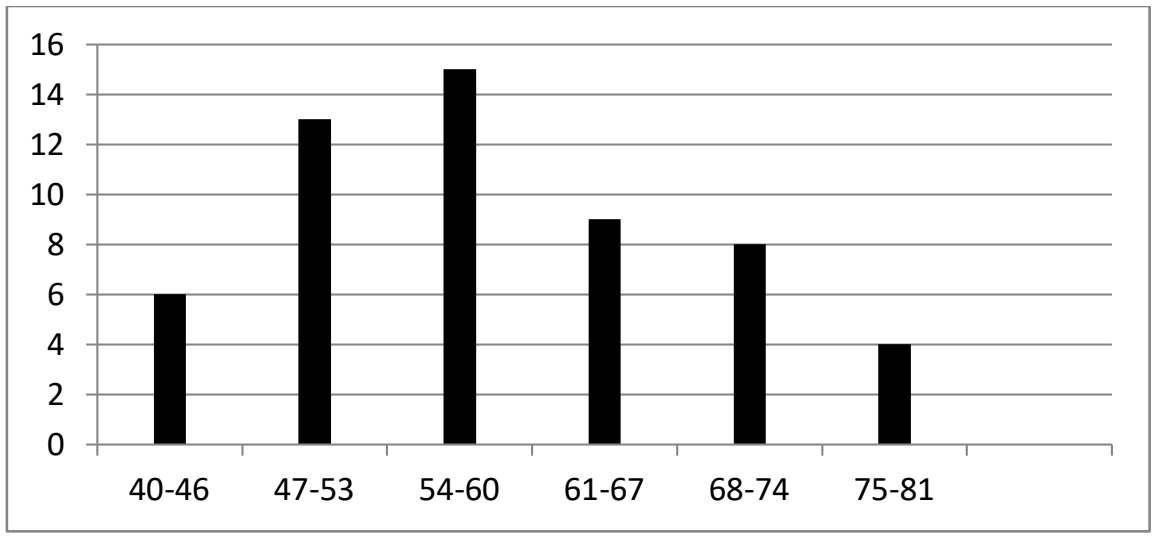

Gambar 2. Histogram motivasi belajar siswa

Selanjutnya tingkat pencapaian responden pada masing-masing variabel yaitu, untuk variabel motivasi belajar siswa diukur dengan menggunakan angket pernyataan variabel motivasi belajar siswa sebanyak 21 butir dengan rentang skor $1-4$ terdiri dari 6 indikator, penentuan klasifikasi data didasarkan pada selang persentase. Hasil analisis angket penelitian untuk variabel motivasi belajar siswa yang terdiri 6 indikator terdapat pada lampiran 12. Untuk menentukan klasifikasi nilai atau skor tingkat capaian responden terendah pada indikator dapat mempertahankan pendapat sebesar $62,88 \%$ dengan kategori tinggi sedangkan yang tertinggi pada indikator ketekunan dalam belajar sebesar 72,58\% kategori tinggi.

Keterampilan Mengajar Guru

Data variabel persepsi siswa tentang keterampilan mengajar guru di SMA 1 Sungai Pua didapat dari penyebaran angket padai 55 orang responden, skor motivasi belajar siswa yang diperoleh menyebar dari skor terendah 67,00 , skor tertinggi 99,00, skor total sebesar 4697,00, mean $=85,4000$, median $=$ 
85,0000, modus $=80,00$, dan Standar deviasi 7,29688. Dari perhitungan dasar motivasi siswa diketahui bahwa skor jawaban menyebar dari skor terendah 67 sampai yang tertinggi adalah 99, sehingga rentang nilai yang tersebar pada sampel adalah $99-67=32$.

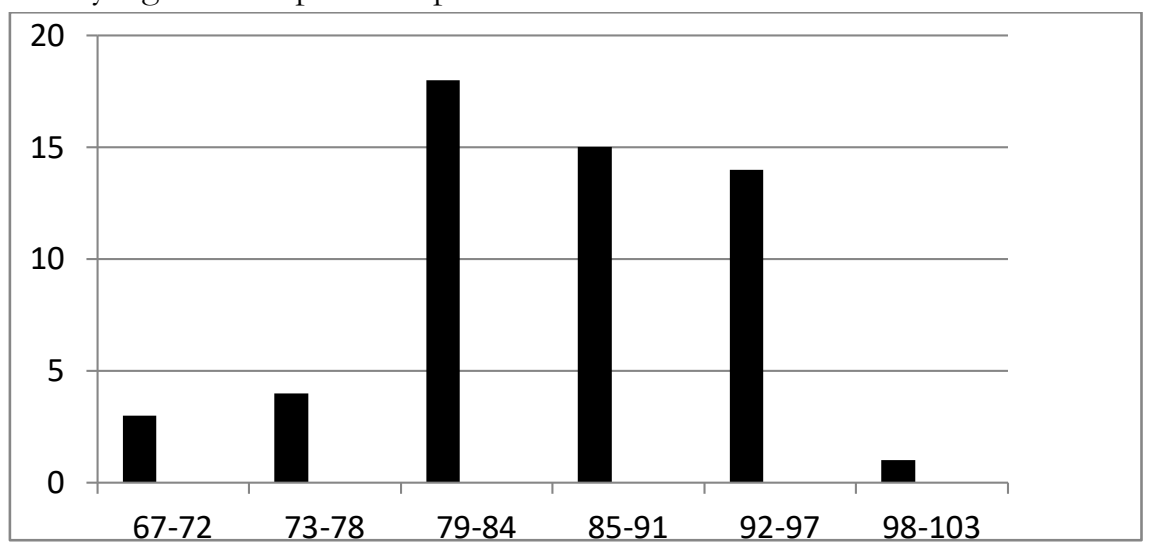

Gambar 3. Histogram keterampilan mengajar guru

Berdasarkan uji kolerasi yang dilakukan dengan menggunakan rumus kolerasi product-moment, pengujian dilakukan dengan program bantuan spss 15 dan Microsoft office excel antara keterampilan mengajar guru dengan motivasi belajar siswa SMA N 1 Sungai Pua Kabupaten Agam dengan perbandingan harga $\mathrm{r}$ yaitu $\mathrm{r}$ hitung $<$ rtabel untuk hubungan yang tidak signifikan (H0 diterima) sedangkan jika rhitung $>$ rtabel berarti terdapat hubungan yang signifikan (H1 diterima). Hasil yang diperoleh analisi ini $r$ hitung 0,508 sedangkan $r$ tabel 0.266,njadi $r$ hitung 0,508 $>\mathrm{r}$ tabel 0.266 (lampiran 8). Hal ini berarti bahwa hipotesis $\mathrm{H} 0$ sedangkan $\mathrm{H} 1$ diterima yang menyatakan terdapat hubungan yang signifikan antara hubungan keterampilan mengajar guru dengan motivasi belajar siswa.

Berdasarkan hasil analisis korelasi dari kedua variabel yaitu variabel persepsi siswa terhadap keterampilan mengajar guru $(\mathrm{X})$ dan variabel motivasi belajar siswa $(\mathrm{Y})$ dengan koefesien korelasi dalam penelitian ini adalah 0.508. Jika ditafsirkan tingkat korelasi suatu pengukuran berdasarkan pedoman Arikunto (2002) yang terdapat pada tabel 5 maka diperoleh koefesien korelasi persepsi siswa terhadap keterampilan mengajar guru dengan motivasi belajar siswa berada pada interval 0.40 - 0.60.

Berdasarkan pengujian hipotesis yang dilakukan dengan menggunakan rumus korelasi productmoment diperoleh hasil perbandingan rhitung lebih besar dari rtabel dengan nilai rhitung $0.508>$ rtabel 0.266 dan setelah itu dilakukan pengujian dengan rumus koefisien determinan (KD) untuk menentukan berapa besar sumbangan keterampilan mengajar guru diperoleh hasil sebanyak $25.80 \%$. Hal ini menunjukkan bahwa antara persepsi siswa tentang keterampilan mengajar guru dengan motivasi belajar siswa SMA N 1 Sungai Pua terdapat hubungan yang signifikan dan memberikan kontribusi yang atau sumbangan dalam pelaksanaan proses pembelajaran.

Meskipun dari hasil uji hipotesis menunjukkan bahwa terdapat hubungan yang signifikan antara persepsi siswa tentang keterampilan mengajar guru dengan motivasi belajar siswa yang berarti $\mathrm{Ha}$ diterima, namun secara khusus tidak semua indikator keterampilan mengajar guru mempunyai hubungan yang signifikan terhadap motivasi belajar siswa, dan bisa dilihat berapa besar sumbangan indikator keterampilan mengajar guru terhadap motivasi belajar. Untuk itu lebih lanjut dibahas satu persatu untuk melihat apakah ada sumbangan antara persepsi siswa tentang keterampilan mengajar guru 
dengan motivasi belajar. Hubungan keterampilan mengajar guru dengan indikator keterampilan mengajar guru yang berpengaruh terhadap motivasi belajar siswa.

Tabel 4. Hasil uji korelasi keterampilan mengajar guru dengan indikator keterampilan mengajar guru yang berpengaruh terhadap motivasi belajar siswa

\begin{tabular}{|l|l|l|l|l|l|l|l|l|l|}
\hline & $\begin{array}{l}\text { Iindikator } \\
1\end{array}$ & $\begin{array}{l}\text { Indikat } \\
\text { or }\end{array}$ & $\begin{array}{l}\text { Indikat } \\
\text { or }\end{array}$ & $\begin{array}{l}\text { Indikat } \\
\text { or }\end{array}$ & $\begin{array}{l}\text { Indikat } \\
\text { or }\end{array}$ & $\begin{array}{l}\text { Indikat } \\
\text { or }\end{array}$ & $\begin{array}{l}\text { Indicat } \\
\text { or }\end{array}$ & $\begin{array}{l}\text { Indicat } \\
\text { or }\end{array}$ & $\begin{array}{l}\text { Indicat } \\
\text { or }\end{array}$ \\
\hline rhit & 0.232 & 0.856 & 0.288 & 0.056 & 0.554 & 0.289 & 0.352 & 0.284 & 0.10 \\
\hline rtab & 0.266 & 0.266 & 0.266 & 0.266 & 0.266 & 0.266 & 0.266 & 0.266 & 0,66 \\
\hline KP & 0 & $73 \%$ & $8.33 \%$ & 0 & $30.75 \%$ & $8.3 \%$ & $12.4 \%$ & 0.06 & 0 \\
\hline
\end{tabular}

Dari tabel di atas dapat dilihat ada beberapa indikator persepsi siswa tentang keterampilan mengajar guru yang tidak mempengaruhi motivasi belajar siswa pada indikator pertama, ke empat dan ke Sembilan. Indikator pertama yaitu keterampilan mengelola tugas rutin kelas tidak mempunyai hubungan yang signifikan terhadap motivasi belajar siswa ini dapat dilihat dari hasil $r$ hitung 0.232 yang lebih kecil terhadap $\mathrm{r}$ tabel 0.266. Ini dapat dilihat dilapangan bahwa guru kurang melakukan mengelola tugas rutin seperti melakukan absensi, memeriksa persiapan siswa untuk belajar baik itu persiapan mental maupun persiapan alat tulis belajar, menyediakan alat bantu (media) yang tepat dll, sehingga siswa kurang termotivasi untuk belajar.

Pada indikator empat keterampilan mendemonstrasikan khasanah metode mengajar, pada indikator ini juga tidak mempunyai hubungan yang signifikan terhadap motivasi belajar siswa ini dapat dilihat dari hasil $r$ hitung $-0,056$ yang lebih rendah sekali dengan $r$ tabel 0.266, dapat disimpulkan tidak memberikan sumbangan terhadap motivasi belajar siswa. Dari lapangan dapat dilihat guru kurang tepat mengimplementasikan kegiatan belajar, menggunakan metode pembelajaran sehingga siswa-siswa kurang tertarik untuk memperhatikan guru menyampaikan materi hal ini disebabkan dalam penyampaian materi guru memakai metode ceramah sehingga siswa bosan dalam belajar.

Pada tabel di atas dapat dilihat bahwa persepsi siswa yang mempunyai hubungan yang signifikan terhadap motivasi belajar siswa yaitu pada indikator ke dua, ke tiga, ke lima, ke enam, ke tujuh dan ke delapan. Indikator ke dua yakni menggunakan strategi pembelajaran, pada indikator ini mempunyai hubungan yang signifikan terhadap motivasi belajar siswa ini dapat dilihat dari hasil $\mathrm{r}$ hitung 0.856 lebih besar dari pada $\mathrm{r}$ tabel 0.266 dapat disimpulkan indikator ini memberikan sumbangan terhadap motivasi belajar, karena dilapangan dapat dilihat guru sudah tepat menggunakan strategi pembelajaran sesuai dengan karakter dan kemampuan siswa di setiap kelas, karena di setiap kelas siswa mempunyai karekter dan kemampuan yang berbeda - beda. Dengan mengetahui hal tersebut guru juga harus mempunyai strategi pembelajaran yang juga berbeda setiap kelas sesuai dengan kebutuhan siswa 
baik itu dalam penggunaan media, metode pembelajaran dan kegiatan selama pembelajaran sehingga siswa lebih termotivasi dalam belajar.

Pada indikator keterampilan berkomunaksi dengan siswa, pada indikator ini mempunyai hubungan yang signifikan terhadap motivasi belajar siswa ini dapat dilihat hasi perolehan nilai $\mathrm{r}$ hitung sebesar 0.288 lebih besar dari $\mathrm{r}$ tabel 0.266 , berarti indikator ini meberikan sumbangan terhadap motivasi belajar siswa. Hal ini dapat dilihat dilapangan bahwa guru dapat berkomunikasi dengan baik kepada siswa dalam menyampaikan materi pelajaran baik itu komunikasi lisan maupun tulisan. Guru dapat menyampaikan maksud dan tujuan dari pelajar tersebut yang mudah dipahami dan dicerna oleh siswa, oleh karena itu siswa lebih tertarik memperhatikan guru dalam menyajikan materi pelajaran dan dapat disimpulkan siswa termotivasi untuk belajar.

Pada indikator keterampilan mendemonstrasikan penguasaan mata pelajaran dan relevansi, pada indikator ini mempunyai hubungan yang signifikan terhadap motivasi belajar siswa ini dapat dilihat hasil perolehan nilai $\mathrm{r}$ hitung 0.554 lebih tinggi dari hasil $\mathrm{r}$ tabel 0.266 berati indikator ini memberikan sumbangan terhadap motivasi belajar siswa. Ini dapat dilihat dilapangan guru dapat mendemonstrasikan penguasaan materi pelajaran dengan baik dan mempunyai relevansi yang cukup terhadap kebutuhan siswa. Dengan demikian dalam penyampaian materi pelajaran yang disajikan oleh guru dapat mengenal maksud dan tujuan pentingnya topic tersebut, sehingga siswa lebih semangat mendengarkan dan memperhatikan guru dalam menyampaikan meteri pelajaran karena guru dalam menyajikan pelajaran mudah dimengerti oleh siswa.

Pada indikator keterampilan mendorong dan menggalakan keterlibatan proses pembelajaran, pada indikator ini mempunyai hubungan yang signifikan terhadap motivasi belajar siswa ini dapat dilihat hasil nilai $r$ hitung 0.289 lebih besar dari $r$ tabel 0.266 ini berarti pada indikator ini memberikan sumbangan terhadap motivasi belajar siswa. Ini dapat dilihat dilapangan dalam proses pembelajaran guru dapat menggalakan keterlibatan siswa, didalam kelas tidak hanya guru saja yang mendominasi situasi kelas, melainkan guru juga melibatkan siswa, memberikan pertanyaan-pertanyaan kepada siswa dan memberikan kesepatan kepada siswa untuk bertanya mengenai materi yang disampaikan serta memberikan respon yang positif terhadap pendapat siswa, sehingga siswa lebih merasa senang dalam mengikuti pelajaran.

Pada indikator keterampilan melaksanakan evaluasi hasil belajar, pada indikator ini mepunyai hubungan yang signifikan terhadap motivasi belajar ini dapat dilihat hasi perolehan $\mathrm{r}$ hitung 0.352 lebih besar dengan $r$ tabel 0.266 yang berarti indikator ini memberikan sumbangan terhadap motivasi belajar siswa. Keterampilan melaksanakan evaluasi sangat penting dalam proses pembelajaran, karena pelaksanaa evaluasi bertujuan untuk melihat seberapa besar kemampuan siswa memahami pelajaran yang disampaikan oleh guru. Di lapangan dapat dilihat bahwasanya guru telah melaksanakan evaluasi hasil belajar, baik evaluasi selama proses pembelajaran (awal dan akhir pembelajaran). Guru memberikan kesempatan kepada siswa untuk bertanya, memberikan pertanyaan-pertanyaan atau soalsoal yang sesuai dengan materi atau topik yang dipelajari dan memberikan penilaian terhadap hasil yang diperoleh oleh siswa, hal ini akan menyebabkan siswa termotivasi untuk belajar dengan membaca dan memahami materi yang akan disampaikan oleh guru agar siswa mampu menjawab pertanyaan guru dengan benar, dan siswa ingin mendapatkan nilai yang bagus.

Pada indikator menutup pembelajaran, pada indikator ini mempunyai hubungan yang signifikan terhadap motivasi belajar siswa, ini dapat dilihat hasil perolehan nilai $r$ hitung 0.284 lebih besar dari $r$ 
tabel 0.266, berarti pada indikator ini memberikan sumbangan terhadap motivasi belajar siswa. Berdasarkan dilapangan pada akhir pembelajaran guru hampir melaksanakan kegiatan dalam menutup pelajaran seperti member soal atau tes, memberikan rangkuman, dan melakukan tindakan lanjut seperti menyampaikan dan member sedikit gambaran materi pelajaran yang akan di pelajari untuk minggu selanjutnya, dengan demikian siswa mepersiapkan dirinya dirumah sebelum melanjutkan materi yang akan disampaikan oleh guru seterusnya.

Berdasarkan hasil penelitian yang telah dipaparkan di atas terbukti bahwa terdapat hubungan yang signifikan antara persepsi siswa terhadap keterampilan mengajar guru dengan motivasi belajar siswa. Namun tidak semua indikator keterampilan mengajar guru yang mempunyai signifikan terhadap motivasi belajar siswa. Pada indikator yang tidak mempunyai hubungan yang signifikan dengan motivasi belajar siswa, dapat disimpulkan guru kurang trampil dalam mengajar pada keterampilan mengajar tertentu, sehingga siswa kurang mendapatkan stimulus atau rangsangan yang didapatkan oleh siswa dari keterampilan mengajar guru yang nantinya akan menimbulkan suatu repon berupa persepsi negatif terhadap keterampilan mengajar guru dan kurang termotivasi dalam belajar.

Sedangkan untuk indikator keterampilan mengajar guru yang mempunyai hubungan signifikan dengan motivasi belajar siswa, dapat disimpulkan bahwa guru telah trampil pada keterampilan mengajar tersebut. Sehingga siswa mendapatkan stimulus atau rangsangan yang didapatkan siswa dari keterampilan mengajar guru. Stimulus atau rangsangan yang diberikan guru pada siswa akan direspon siswa dengan baik berupa suatu tanggapan atau persepsi positif terhadap keterampilan mengajar guru, yang nantinya siswa akan terangsang untuk belajar dan memiliki motivasi belajar yang baik.

\section{Kesimpulan}

Secara umum terdapat hubungan yang signifikan antara variabel keterampilan mengajar guru dengan motivasi belajar sejarah siswa SMA N 1 Sungai Pua yang dapat dilihat dari hasil uji hipotesis dengan rumus korelasi product-moment dengan pengujian keberartian korelasi dilakukan dengan menggunakan rumus uji-t. Setelah dilakukan uji $\mathrm{t}$ diperoleh $\mathrm{t}$ hitung $=4,2934>$ ttabel $=\alpha=$ $0,05=2,00575$ dengan besar kontribusinya sebesar 25,80\%. Hal ini berarti Ho ditolak dan Ha diterima, sehingga hipotesis yang mengatakan "Terdapat hubungan yang signifikan antara keterampilan mengajar guru dengan motivasi belajar siswa sejarah SMA N 1 Sungai Pua". Hal ini berarti motivasi belajar siswa secara umum dipengaruhi dari persepsi siswa tentang keterampilan mengajar guru yang baik dan tepat sehingga siswa akan termotivasi untuk belajar.

Persepsi siswa yang tidak mempunyai hubunngan terhadap motivasi belajar siswa adalah indikator pertama keterampilan mengelola tugas rutin kelas, ke empat keterampilan mendemonstrasikan khasanah metode pengajaran, dan indikator ke Sembilan kesan umum pelaksanaan pembelajaran. Pada indikator ini tidak mempunyai hubungan yang signifikan terhadap motivasi belajar siswa karena sesuai hasil $\mathrm{r}$ hitung lebih kecil dari $\mathrm{r}$ tabel, berarti indikator ini tidak memberikan sumbangan pada motivasi belajar siswa yaitu tekun dalam belajar, ulet, senang dalam belajara, bekerja mandiri, dapat mempertahankan pendapat dan tidak mau melepaskan apa yang diinginkan, karena dilapangan guru kurang melaksanakan keterampilan yang sesuia dengan indikator tersebut.

Persepsi siswa tentang keterampilan mengajar guru yang mempunyai hubungan signifikan terhadap motivasi belajar siswa yaitu indikator ke dua, ke tiga, ke lima, ke enam, ke tujuh, dan ke 
delapan, hal ini dapat dilihat nilai $r$ hitung lebih besar dari pada $r$ tebel, berarti pada indikator tersebut memberikan sumbangan terhadap motivasi belajar siswa. Dapat disimpulkan dilapangan pada indikator tersebut guru telah melakukan keterampilan mengajar guru dengan baik yang dapat menumbuhkan motivasi belajar siswa.

\section{Ucapan Terimakasih}

Terimakasih penulis ucapkan kepada semua yang pihak yang terlah membanyu dan memberi dukungan dalam penulisan ini yang tidak dapat disebutkan satu persatu. Sehingga tulisan ini, dapat selesai tepat waktu.

\section{Referensi}

Ahmad, Rohani. 2004. Pengelolaan Pengajaran. Jakarta: PT Rineka Cipta

Ali, Muhammad. 2008. Guru Dalam Proses Belajar Mengajar. Bandung: Sinar Baru Algesindo Offset

Arikunto, Suharsimi. 2006. Prosedur Penelitian. Yogyakarta:Rineka Cipta.

Budiningsih, A. (2005). Belajar dan pembelajaran. Jakarta: Rineka Cipta.

Dalyono, M. (1997). Psikologi pendidikan. Penerbit Rineka Cipta.

Dimyati, D., \& Mudjiono, D. (2002). Belajar dan Mengajar.

Elida, P. (1989). Motivasi Dalam Belajar. Depdikpub, Jakarta.

Hamalik, O. (2000). Psikologi belajar dan mengajar. PT Sinar Baru Algensindo.

Hasibuan, JJ \& Moedjiono.1993. Proses Belajar Mengajar. Bandung: PT Remaja Rosdakarya. Dalam http://sambasalim.com/pendidikan/keterampilan-mengajar-guru.html

Iskandar. 2008. Metodologi Penelitian Pendidikan Dan Sosial (kuantitatif dan kualitatif). Jakarta: Gaung persada press

Moh.Uzer Usman. 2008. Menjadi Guru Profesional. Bandung:PT Remaja Rosdakarya

Mulyasa, E. (2005). Menjadi guru profesional menciptakan pembelajaran kreatif dan menyenangkan. Bandung: Remaja Rosdakarya.

Nasional, D. P. (2005). UU RI No. 14 tahun 2005 tentang Guru dan Dosen. Jakarta: Departemen Pendidikan Nasional.

Nasution, S. (1995). Didaktik asas-asas mengajar. Bumi Aksara.

Prayitno, Elida.2007. Motivasi Dalam Belajar. Jakarta: Depdikbud

Robbins, S. P. (2000). Administração: mudanças e perspectivas. Saraiva. 
Sardiman, A. M. (2008). Interaksi dan motivasi mengajar. Jakarta: Raja Grafindo Persada.

Winkel, W. S. (1983). Psikologi pendidikan dan evaluasi belajar. Gramedia.

Yutmini, S. (1992). Strategi belajar mengajar. Surakarta: FKIP UNS. 